\title{
LECTURE TO THE CONGRESS,
}

\author{
BY CHRISTOPHER CHILDS, M.A., M.D.Oxon., D.P.H., \\ Lecturer on Bacteriologr in relation to Hygiene, \\ University College, London. \\ (MENibr.)
}

\section{TIIE PRETENTION OF POLI,UTION OF OUR STREAMS AND RIVERS.}

Fron time immemorial it appears to have been the custom with the people of this and also of other conntries, whenever ruming water in the form of hrook, or stream, or river was conceniently at hand, to commit all the excreta of the individual, the refuse of the household, and the waste prolucts of industries to that water.

When no ruming water was near the same foul products were cast upon the soil or into pits, there to putrefy and give forth poisonous gases to the air, to form a breeding gromil for those microscopic germs which we now know to be the causes of so much disease and death, and to poison the subsoil water; that same water which was used for cleansing puposes, and for the food of those rery people who caused its pollution.

It would be idle for me to recilpitulate before this audience the tragic history of sickness, misery, deatl, and financial loss which hare unceasingly been recorded, even up to this very day, owing to this innate carelessness with regard to the safe and fitting disposal of human excreta and domestic refuse.

And yet, in spite of these direful warnings, in spite of the tenching and unwearying efforts of the Apostles of Preventive Medicine, in spite of all modern sanitary reforms, the accumulated legislature of the last sixty years, and our adranced knowleclige with regard to the laws of health, this national custom still prevails, and no works are necessary to prove that pollution is common throughout the length and breadth of the land.

The question which constantly calls for our serious attention is-How this custom is to be altered? How the people of this country are to be induced to keep soil water and air uncontaminated by human excreta and the refuse of houselolds and factories.

In a paper, introducing a discussion on $\mathrm{W}^{\top}$ aterborne Typhoid 
Fever, which I was invited to read before this Institute last March, I ventured to suggest that a Conference on River Pollution might be made a constant item in the Annual Congress. The Council deciled to appoint a Standing Committee on River Pollution, and requested me to give an address on this subject at the present Congress-an honour for which $I$ take this opportunity of tendering my grateful thanks.

I was somewhat dismayed to find later on that the discussion of River Pollution was to form part of the programme at the meeting of the British Medical Association in Edinburgh, and also at the Congress of the Royal Institute of Public Health at Dublin, fearing that it would be necessary to throw much of what I had written into the waste paper basket. It was consoling, however, to realise that this important question is being taken up throughout the United Kingrlom, and that I should be able to enlarge upon certain points which $I$ think require our special attention.

The discussion at Dublin I unfortunately missed, nor have I succeeded in finding an account of it.

The admirable paper read by Dr. Maclean Wilson at Edinburgh, together with the practical and instructive discussion which followed it, is reported in the "British Medical Journal," of Aug. 13th. It should be studied by everyone interested in the subject.

We have also to thank Professor Glaister for his excellent and comprehensive address on the "Pollution of Scottish Rivers," which he delivered to the Philosophical Society of Glasgow in January, 1897.

Professor Glaister made a special inquiry into the nature and amount of pollution existing in the industrial counties of Scotland, with the result that lie found "the extent and incidence of river pollution substantially the same to-day as it was 25 years ago, when the Commissioners macle their inquiries into the condition of rivers."

Originally, I intended to have male a similar inquiry in to the nature and extent of river pollution in England and Wales, but with the short time at my disposal it became obrious that such an undertaking was impossible. The results of such an inquiry would be of the greatest service. Possibly it may come within the scope of the present Royal Commission on Sewage, or it might be carried out without much cost or difficulty by the Lucal Government Buard, with the help of the Medical Officers of Health.

It would probably be found that things are no better on the south side of the Trweed than they were shown to be on the north. 
In any case it is generally admitted that the Rivers Pollution Act of 1876 has generally and persistently failed in the purpose for which it was intended, and that pollution has very generally continued and progressed unchecked in defiance of the law, and of the many efforts made to reduce it.

\section{Difficulties in the way of Reform.}

The chief difficulties in the way of the much desired reforms are the ignorance and indifference of the people; the great cost of sewage purification and the uncertainty with regard to the best means to be employed; last, but not least, the defects in the law itself, and the impotence of the measures provided for its administration.

One of the first and greatest obstacles in the path of progress is undoubtedly the apathy and indifference with regard to pollution which is suffered to occur and to be persisted in in all parts of the kingdom.

We cannot hope for thorough and effective legislation until the people have been roused from this indifference; until they are made fully conscious of the disgusting contamination to which our water supplies are so commonly liable; are convinced of the consequent danger to which they are so constantly exposed, and insist upon those reforms which will afford them reasonable protection. This indifference is due in a large measure to habit and custom, but chiefly to ignorance; ignorance of different kinds and degrees, and common to all classes; ignorance of the simplest Jaws of nature, of the most obvious laws of health, of the nature and causes of those diseases which are conveyed through water, and of the ways in which such diseases spread from man to his neighbour or to a large community. Such ignorance can only be dispelled by systematic, persistent, and widespread eclucation in these matters.

Next to the obstruction of ignorance and indifference, the great cost of purification of sewage and trade refuse, togetler with the constant uncertainty with regard to the best methods of purification, have proved frequent hindrances to the wellintentioned efforts for reform made by the more enlightened members of local communities. At the present time, however, we may congratulate ourselves that there is a definite prospect that these two difficulties will be reduced to a minimum. The researches and practical results obtained by the Massachusetts State Board of Health, by Scott Moncrieff, Dibdin, Dupré, Donald Cameron, and others, plainly demonstrate that the great difficulty, uncertainty, and cost of purification, which have blocked the way for so many years, have been in a large measure 
due to our misconception of the true principles by which we should be guided in dealing with domestic sewage. $\mathrm{W}$ e have constantly endeavoured to thwart and destroy those natural agents for the purification of foul matters, the liquefying and nitrifying bacteria, as if they were our greatest foes, instead of our best and most indispensable allies.

The discovery and practical application of the so-called biological methods of purification form one of the greatest triumphs of modern sanitary science.

These methods have been on trial for sufficient time and on sufficiently large scale, to prove that they have to a great extent solved the clue to this most difficult and complicated problem. If they finally and completely succed, they will remove the chief practical difficulties which block the way, and will save the country the ammual expenditure of many millions.

It will be well at this point to consider in the light of our more recent experience, the exact objects to be aimed at in the process of sewage purification, and the means by which such purification may be obtained and secured.

The chief object of purification of sewage and refuse is to secure that the effluent from any sewage, manufacturing process, or filth accumulation to any "stream" (as defined in Clause 20 of the Rivers Pollution Prevention Act of 1876), shall be purified in such a way that it shall not cause the water of the stream to be poisonous or dangerous to the health of those who drink it; nor be detrimental to the manufactures for which it may be used, nor offensive to the sight or smell, nor destructive to fish, nor obstructive to the flow of the stream. Of these conditions, that which makes the water poisonous or dangerous to the health of those who drink it, is the most important one for our consideration, and the most difficult to define.

How are we to define the term poisonous or dangerous to health?

From the time when serious attention was given to the pollution of our streams by foul matters, culminating in the work of the River's Pollution Commission of 1868, great stress has been laid, and rightly laid, upon the amount of effete organic matter contained in the effluents and in the water used for drinking purposes.

The limits of the amount of organic matter to be allowed in any effluent, as gauged with the help of Frankland's method by the amount of organic carbon and organic nitrogen in a given quantity of the fluid effluent, were laid down in the well known suggestions of the Rivers Pollution Commission.

At that time, however, the germ theory of disease was hardly known : bacteria were not recognised as the active agents, the 
vera causa of infectious diseases, and consequently the amount of organic matter in an effluent or in water became the recognised chief test of the danger or safety of these fluids.

Now, although the amount of organic matter (and of certain inorganic compounds, such as chloricles) in a natural water is a most delicate test and indication of contamination with animal or vegetable matter, whilst in an efluent it is a measure of the putrescible matter which still remains to be oxidised, it cannot be too much insisted upon that the amount of organic matter in an effluent or in water, as gauged by any of the recognised chemical methods (Frankland's, Wanklyn's, Tidy's, and others) is not a test of the actual poisonous chinacter of those fluids.

It is generally accepted that water polluted by sewage is always dangerous to health, and frequently the actual cause of outbreaks of cholera and typhoid fever. But it does not follow that the quantity or quality of organic matter which is dissolved in the water determines these outbreaks. In fact water strongly contaminated with sewage may be drunk for an indefinite time without causing cholera or typlooid ferer.

It is necessary to lay striss upon these statements because there is a tendency to regard a sewage eftluent as "purified" when the putrescible matter contained in it is reduced down to a certain standard, whilst the idea, even in these days, seems to be prevalent that the actual poisonous or wholesome character of water for drinking may be decided simply by chemical analysis.

It is only under certain conditions that water so polluted causes these diseases; those conditions being the introduction of the specific poisons of cholera or of typhoid fever under circumstances fivourable for their development and convection.

The poisons of cholera and typhoid fever, it has long been known, are contained in the excreta of patients suffering from those diseases, and according to the accepted teachings of bacteriology those poisons consist of living bacteria, the spirillum cholere Asiatica of Koch, and the bacillus typhosus of Eberth and Gafficy.

Water strongly contaminated with scwage, unless it contains the bacterium of cholera or typhoid, camnot cause choleral or typhoid fever, any more than grapes may be gathered from thorns or figs from thistles.

Thongh the guantity and quality of organic matter in any water are of great importance as an index of the degree, lind and source of pollution, they are not a measure of danger or safety. The real factor which determines the danger or safety of water for drinking purposes is the presence or absence of living germs of disease, the "pathogenic bacteria." 
What diseases have definitely been proved to be due to drinking water contaminated with human excreta?

- It must be admitted that they are but few.

Most authoritics agree that cholera and typhoid fever are the only infectious diseases conveyed by drinking water in this country.

It is probable, however, that diarrhoea and various ill defined low states of health may be conveyed in the same way.

Now, since cholera invades our shores only at intervals, and each recent invasion has been more and more successfully repelled by the sanitary measures so admirably organised against it, the most important and most constant object in sewage purification, having regard to the public health, is the clestruction of those micro-organisms which are recognised as the cause of typhoid fever, the bacilli typhosi of Ehertl and Gaffky.

The first step, howerer, for the prevention of infection in our water supplies with the fever poison, is not the purification of sewage but the clestruction of the fever germs before they have escaped from the sick room of the patient into the soil, the sewers, or the drinking water. Sufficient attention has not been paid to the fact that when the typhoid bacilli have been allowed to escape alive from the sick roum and dwelling of the ferer patient into the drain or cess-pit, or other receptacle, it becomes most difficult, if not impossible, to trace or detect them, or to effectively clestroy them with germicilal agents.

Until the living bacilli (contained in the excreta) have been tirus conveyed to the outer world, they are entirely at the mercy of the nurse, on whom is laid the serivus responsibility of protecting herself as well as others from the living poison by killing it at the earliest opportunity.

That this responsibility is not sufficiently realised is shown by the too great frequency with which those engaged in nursing the patients become infected, not only amongst the poor and ignorant classes, but even in some of our great liospitals.

A gainst the invasion of typhoid fever the nurses hold the first line of defence; and it is no exaggeration to say that the first and most important steps for the prevention of pollution of our water supplies with infections material, and saffeguarding the people from typhoid fever, begin at the bedside of the typhoid fever patient.

I feel compelled to give more than a passing notice to the snbject of disinfection in cases of typhoil fever, because I am assured that this disinfection is most imperfectly performed throughout the comitry.

If complete disinfection were carried ont in all cases of typhoid ferer, this disease would rappidly disalplear, and the 
dangers resulting from sewage pollution of our water supplies would be greatly reduced.

What means" have we for securing the destruction of the typhoid bacilli and other pathogenic bacteria, when they have once gained entrance into sewage?

There are no direct experimental proofs that the bacilli of typhoid fever are destroyed in sewage by any of the processes of purification at present in use. Nor is there much prospect of obtaining such proof at present, owing to the great and special difficulty of detecting and rerifying the presence of these bacilli in such fluids as sewage. This difficulty can only be fully realised by those who have had large experience in such investigations; and is clue partly to the absence of any specific active properties peculiar to these bacilli (except in the "serum test"), partly to the strong resemblance between these bacilli and many others which almost invariably accompany them,- - notably those known as "the bacilli of the coli group." It is generally admitted that many of our best bacteriologists have been deceived by this resemblance, and that though the presence of bacilli typhosi have frequently been reported in suspected waters it is very doubtful whether the bacilli have actually been isolated and verified even where the water has been obviously contaminated by excreta of typhoid fever patients.

The experiments of Laws and Andrewes, it is true, inclicate that "sewage does not form a medium in which much if any growth is possible for the bacilli typhosi under natural conditions; and that their deatl is only the matter of a few days or at most a week or two."-(Keport to London County Council, 1894).

Until the results obtained by these observers have been corroborated by repeated experiments under similar and under varied conditions, it would be inadvisable to form a final conclusion or to base any practical system upon them.

An exhaustive investigation of the quality and quantity of micro-organisms to be found in the sewage effluents obtained by different processes at present in use is much to be desired. But such investigations are very difficult, can only be conducted by skilled bacteriologists of great experience, and will require a long time for their completion. Similar information is needed with regard to the vitality of typhoid bacilli in various kinds of water.

Sucl experiments are being carried on at the present time in this country (as well as on the Continent). For instance, Professor Boyce contributes a paper to this Congress on "The Flora of Sewage." 
Dr. Houston is making bacteriological analyses of the crude London sewage. Professor Delépine is maling a "Bacteriological Survey of Surface Water Supplies."

How far may we trust to natural agencies for the destruction of the bacilli typhosi when they have been conveyed by a sewage effluent into a large river such as the Severn or the Thames? Here again we have no direct experimental proof, owing chiefly to those difficulties mentioned above. It has been shown that these bacilli can live for one to three weeks in ordinary drinking water, but it is possible that they may live longer.

From our general knowledge of them, and by analogy, we nay infer that the chances are against their living very long in river water. They do not form spores, and are therefore not very resistant to adverse conditions. Sunlight, it has been shown, has a weakening and inhibitory effect upon them, and probably diminishes their virulence.

It is conceivable that before long some practical and economical method may be devised for completely sterilising sewage effuents so that no living organisms-pathogenic or non-pathogenic-may escape in them into the stream.

If we turn to the evidence of medical statistics and epidemiological facts we find abundant instances which show that the typhoid mortality in towns and cities supplied with water from upland surfaces does not seem to be less than that of towns and cities deriving their water supply from rivers, provided that the river water is efficiently filtered. Such appears to be the case generally on the Continent, in America, and in our own country. This evidence, however, is framentary and incomplete and requires most careful investigation before any final judgment can be formed from it. I am at present engaged in an enquiry with regard to the typhoid mortality of the chief towns and cities of the world in relation to their water supply, soil, drainage, and other conditions, but it will be long before I shall have sufficient evidence for the formation of a definite conclusion.

If we could obtain evidence extended over many years with regard to the mortality from typhoid fever amongst several millions of people drinking water from a river which has been contaminated by sewage, and compare that mortality with the mortality of several millions supplied with water never so contaminated, other conditions being equal, we should have the conditions of an experiment on a vast scale, from which we might hope to form reliable conclusions.

Such conditions we have in the history of our great metropolis. According to the evidence brought before the Royal Commission on the Metropolitan Water Supply (1893), the 
typhoid mortality in London is exceptionally low. When compared with that of fourteen other great Einglish towns, "that have public water supplies which are not excrementally polluted," during the period $1881-18910$, it was found to be very little higher than that of four of these large towns, and lower than that of the remaining ten.

Moreover, all the medical, chemical, and bacteriological experts examined by the Commission stated unlesitatingly that. they knew of no single instance in which the consumption of London water hatd caused disease.

These facts and conclusions are of great import, thongh those who contemplate them have been, and will be, differently impressed by their significance, some being convinced thit water supplied under conditions such as obtain in London must be regarcled as reasonably safe.

Such for instance was the conclusion of the majority of the Royal Commission for the Prevention of Pollution of Rivers of 1868. Such also was the manimous conviction of the Royal Commission from whose report I have just quoted.

Other's, on the contrary, do not consider that water derived from the Thames and Lee can ever be used for drinking purposes with reasonable safety, even though the sewage effluents which enter those rivers be "purified to the lighest extent known to science."

Dr. Bostock Hill, in his excellent paper on "The Safeguarcling and Examination of Public Water Supplies," put the case very clearly and concludes his reasoning thus:- "Does not the teaching of lyygiene, and the sterner teaching of practical experience point to the fact that methols of purification depending on human effort are sometimes found to fail, and that at critical times the imacrinary safeguards cease to exist?"

The case of Altona miglat be quoted in support of this last argument of Dr. Hill's. It will be remembered that in the great cholera epiclemic at Hamburg in the autumn of 1892 , the contignous town of Altona was comparatively free from the disease, although the source of the water supply from the Elbe was far more polluted than that of Hamburg. The escape of Altona was generally attributed to the fact that the water supply was submitted to careful sand filtration, "whilst in Hamburg the Elbe water was distributed in its raw condition as taken from the river."

Nevertheless, in spite of the awful warning immediately before them, a gross flaw in the Altona filters was suffered to pass unnoticed in the following December, and was detected only when too late by a shimp outbreak of disease amongst 
those supplied with water from the rlefective filter. "One of the filters which had been clcaned during the frost had bccome frozen over, and was in consequence not able to retain the bacteria," a fact which was sulssequently proved by bacteriological examination of the water clerived from this special filter.

In any case it is imperative that water supplied from any river or other source which has been polluted in the least clegree by scwage or organic matter, after adequate storage and sedimentation, should be subjected to complete and carefully managed sand filtration, before it is distributed into the water mains.

In dealing with this vexed question whether a river water which is polluted or liable to be polluted with excrement, can ever be regarded as a reasonably safe source for public water supplies or not, I wish not to abuse the position in which you have done me the honour of placing me by any special pleading for one side or the other, where such large interests are at stake.

But in view of the facts and arguments which $I$ hare laid before you, I feel compelled to artopt and uphold the following principles.

(1) That where a community is able to obtain a water supply free from the possibility of any contamination instcad of one liable to such contamination, that community is bound $f n r^{\circ}$ the sake of the safety and the welfare of its citizens to procure the supply which is above suspicion.

(2) That in cases where there is no alternative but to use the water of some adjoining river, or other source liable to pollution, no measures should be neglected whereby poisonous and noxions elements may be prevented from finding entrance into the water, and whereby the last traces of such poisonous elements, if they have found entrance, may witl certainty be removed through the best means arailable.

The city in which we have the privilegre of meeting to-day is greatly to be congratulated upon baving accuired a magnificent and unrivalled water-shed amongst the mountains of Wales, through which an ample and pure supply is secured for its growing population, the whole gathering ground and every tributary and spring being the property and under the protection of the Corporation. Through the kindness of the engineer, Mr. Mansergh, who is giving an account of this great undertaking to the Congress, I was cmabled to risit the works this spring, and can bear witness to the grandeur and completeness of this colossal triumph of engineering skill and human enterprise.

Birmingham was compelled, owing to its high position and 
the absence of sufficient water supply at hand to go far afield. But to many towns and cities such irreproachable watersheds are not available, and they must rely upon neighbouring springs streams or rivers for their supply. Moreover, difficulties of a serious and complicated nature already begin to be felt, owing to the race and competition for upland water supplies.

All these considerations serve to indicate and emphasize the urgent necessity of preventing and utterly abolishing the pollution of our streams and water-courses.

\section{"The Best Practichibe and Avallale Means."}

Bacteriological and epidemiological evidence, it will be seen, give little or no help at present in deciding on the "best practicable and reasonably available means" for destroying the pathogenic bacteria in sewage. Until further evidence is forthcoming we must be content with those means which are hest for purifying an effluent to the extent that it will not cause putrefactive or other offensive processes to occur when it lias passed into a stream.

As mentioned previously, the difficulty of exactly defining this term, "the best practicable and available means," has proved one of the many obstacles to progress.

The treatment by irrigation on land which has so generally been insisted upon (subsequent to filtration and precipitation, or to both), has proved a heavy tax to many communities, and a frequent obstacle to the adoption of any process of purification at all.

In many cases, either the ligh cost of land, or its utter unsuitability for the purpose, or its position have prerented it from being any thing like available or practicable.

But there is erery reason for hoping that by the new biological methods recently established, a way will be found by which the difficulties may be overcome, and though these methods may not altogether supplant that of irrigation, they will no doubt simplify the process in some cases and diminish the amount of land required, and in others do away with the necessity of land altogrether.

Whichever biological system proves the best, it has undoubtedly been shown that by withholding chemicals altogether, and by placing the countless hosts of bacteria which throng every drop of domestic sewage under conditions favourable for their development and activity, the solid materials of sewage may be broken down and liquefied, and subsequently oxidised so as to form a clear and non-putrescible effluent.

How far these methods will succeed in dealing with the 
manifold and complicated materials which are present in sewage, mixed with tracle effluents, remains to be seen.

Almost every noxious and offensive trade cffluent that exists is probably represented in Lancashire and the West Riding, and as experiments have been for some time carried on at Leeds, Bralford and Sheffield, besides many other places, we shall probably learn before long to what extent the biological processes are interfered with by these effluents, and also the means by which this interference may be checked or altogether counteracted.

\section{Standari) EFrluents.}

The difficulty with regard to standard effluents remains to be considered. The conditions under which those standards have to be determined are so various, and there is so much difference of opinion with regard to them amongst authorities that it seems impossible to define them; although they would greatly facilitate the labours of all those who are concerned with the prevention of pollution. The details of these difticulties were discussed at Edinburgh by Dr. Wilson, who considers that the establishment of a standard is impracticable.

With regard to sewage, howerer, the principle on which a standard of purity should be formed may be detined; viz., that the effluent shall be purified in such a way that it will not undergo offensive putrefaction either by itself or when mixed with the stream into which it flows. "With regard to trade effluents it is to be hoped that the present Royal Commission will lay down some definite lines. Mcanwhile the temporary settlenent of standards might be made in friendly conference between manufacturers and rivers committees, as has been done in some instances with satisfactory results.

\section{Defects in the ACt of 1876.}

We will now consider the law, as it stands, for the prevention. of pollution.

Why is the Rivers Pollution Act of 1876 almost universally condemned as a dead letter?

It has been pointed out again and again that this failure is due chielly to the faulty and imperfect arrangements for the administration of the law, and to certain defects and difficulties in the Act itself.

"The powers for taking action against pollution were entrusted to the sanitary authorities, and these powers are enabling, not compulsory. Now, considering that the sanitary authorities are too of ten the erreatest pollutors, and are constantly subjected to the influence of local and vested interests, 
and the incessant cry for the reduction of the rates, it is not to be wondered at that the administration of these acts has not been attended with success."*

\section{County Councils.}

Great hopes were entertained that, with the establishment of County Councils by the Act of 1888, the indifference and opposition of interested or ignorant individuals and of the smaller local authorities would be overwhelmed and carried along by the larger and more powerful organisation. Unfortunately the administration of the law for the prevention of pollution, which is still purely optional, is from its very nature unpopular, and likely to be avoided. It can only be carried out thoroughly $\mathrm{by}$ men who will systematically devote much time and care to this duty, and will not be unduly influenced by local and rested interests, or by the clamour of short-sighted and parsimonious ratepayers.

Several of the County Councils, no doubt, have done, and are doing much for the prevention of pollution. But all efforts for improvement must be hampered and curtailed by the defects and difficulties at present existing in the Act of $1876^{\circ}$, as well as by the obstacles in the way of administration.

What are those defects and difficulties? Chiefly as follows:

1. The ragueness and incompleteness of many of the terms, such as the definitions of polluting matters, liquid sewage, \&c. (clauses 2 and 3 ).

2. The expense, delay, and uncertainty involved in the restrictions imposed when any authority proposes to enforce the enactment for preventing pollution.

3 . The absence of deterrent penalties.

4. The absence of power of entry for the purpose of taking samples.

These defects are a serious impediment to action, as the joint committees of the Mersey and Irwell and of the West Riding of Yorkshire soon discovered, when they began seriously and systematically to deal with the overwhelming sources of pollution which prevailed in their respective districts. No time was lost by these committees in appealing to Parliament for special Acts, "To make more effectual provision for prevention of pollution," on the ground that "the restrictions contained in the Act (of 1876) were such as to preclude effective action."

Parliament acknowledged the justice and the reasonableness of the appeal by giving assent, and the necessary Acts were passed.

* “Waterborne Typhoid Fever." Jour. San. Inst. Vol. XIX, p. 248. 
Now it is quite certain that everyone, local authorities, or individuals in the kingdom who have concerned themselves with the abolition of iniquitous pollution must have felt the necessity of these reforms, the remedying of the defects which I have mentioned.

And yet a Bill, a private Bill, which embodies all these reforms has been before the House of Commons for years.

This Bill, modelled on the Acts of the Mersey and Irwell Joint Committee and the West Riding Rivers Board, remedies the defects which I have mentioned. It defines and catalogues the various possible kinds of polluting effluents, grants power's of entry to authorities for the taking of samples, and whilst it amply protects the manufacturer from undue embarrassment and expenditure, provides for the proper administration of the law, and the intliction of appropriate penalties upon actual offenders with as little cost, delay, and uncertainty as possible.

Dr. Maclean Wilson, in his introduction of the discussion on Rivers Pollution at Edlinburgh, pointed out that " the Bill as it stands at present is weaker in several respects than either of the Acts upon which it is based."

Dr. Wilson also goes on to say: "The following are some of the points left undecided by the present Bill: the settlement of the question of the right of a manufacturer to discharge his trade refuse into a public sewer, or of the right of the sanitary authority to refuse to allow him so to discharge it; the prohibition of the sludging of mill clams; the power to cause obstructions to the flow of stream to be removed; the absolute prohibition of any new pollutions; the proper supervision of the discharge of compensation water."

These details, it must be admitted, are of first-rate importance, and any conclusions dictated by the experience of these two active rivers Boards is bound to command attention and respect.

On the other liand, one camnot be too careful about overloading any proposed reforms with contentious details. It will be for those in charge of the Bill to decide whether and how many of these additional clauses should be added.

The Bill has been for some years under the care of Sir Francis Sharp Powell, one of the Vicu-Presidents of this Institute. Sharing the fite of many private Bills, it has been talked out and shelved again and again. But Sir Francis intends it to pass; and pass it will. The reforms contained therein will be acknowledged by every intelligent person who studies them, as necessary and just. The time has come when we cannot any longer do without these reforms, and I trust that this Institute 
will give loyal support to its indomitable Vice-Presiclent, by sending a strong, compctent and representative deputation to the Local Government Board, at the carliest opportunity, begging the Board either to adopt this Bill, or to introduce one of its own, on the same or similar lines in the next session of Parliament.

The amendment of these intrinsic defects in the Rivers Pollution Prevention Act, will withont doubt greatly facilitate and promote the abolition of much of the lawless and disceputable pollntion which prevails throughont the United Kingdom.

There still remains, howerer, the great difficulty of getting councils, boroughs, and county boroughs to combine and insist that the law shall be duly observed throughout the whole watersheels in which they are situated. A Borough or a County Council may do its best to set its own house in order to prevent and abolish all pollution within its borders, but it is almost powerless to remove pollution-cxcept when of the grossest and most intolerable kind-in parts of the stream and rivers which are higher up.

The sources and tributarics of at river, for instance, which are above a given town or county, may each contribute its. share of pollution until the sum total of impurity in the main stream becomes intolerably offensive. Yet it will be very difficult to bring conviction home to the individual offenders.

The solution of the difficulty lies in the formation of joint committees, who shall have the supervision and control over whole watersheds, or groups of streams and rivers; committees which shall be fairly representative of all the local interests concerned-of Councils and water companies, manufacturers, and industries,-strong and extensive enough to resist the undue influence of local interests and local jealousies, and to overcome the ris inertice of ignorance and indifference; and whose sole business it shall be to administer the law promptly and without fear or favour for the protection of the waters within their district.

This is no paper scheme baserl on mere theoretical considerations. The Act of 1888 provides for such an organisation in Clause 81 , whereby the formation of such joint committees is sanctioned and regulated.

The idea of the watershed as a proper area for administration is not at all new, but has been aclvocated by many competent authorities.

In April of this year Mr. Middleton read a very interesting paper to the Institute on the desirability of making watershed areas and sanitary districts coterminous. This proposition, however commendable, involves such a revolution and such an 
intricate shifting and resetting of our whole social organisation, that it is not likely to find much farour. But for the constitution of joint, committees for the prevention of pollution no new authorities are required. The existing authorities, who have not sufficient time, and who for reasons previously mentioned are not well qualified to carry out the work thoroughly, will merely depute their office to an authority provided for anil sanctioned by the existing statute.

From the study of a map, showing the principal watershed areas in England and Wales, it will be seen that these areas differ greatly in size. In some cases (e.g., Cornwall) a conjoint committee is evidently undesirable. And in various cases the County Council would be the more suitaljle central authority, as adrocated by Dr. Reid. But in that case it would be desirable to depute this work to a special representative Board.

Fortmately there are joint committees, two of them established long ago which, in their constitution, methods of work, and results produced, present excellent mollels for the whole kingdom, viz.:-The joint committee known as the Thames and Lee Conservancy Boards, the Mersey and Irwell Conjoint Committee, the West Riding River Board, and the Ribble Joint Committee.

The methods employed and the results obtained by these - Joint Committees are, I believe, but little known throughout the kingdom, and as I have been studying this subject for some time I will summarise as briefly as possible the information which I have acquired.

This gives me the opportunity of recording my grateful thanks to those gentlemen who are most actively enganged in the administration of the work of these boards for the courteous and candid manner in which they have put all available information at $\mathrm{my}$ disposal, viz., to $\mathrm{Mr}$. Gough, Secretary of the Thames Conservancy Board; Major Lamorock Flower, Sanitary Engrineer of the Lee Conservancy Boald, and to Mr. Tatton, Dr. Maclean Wilson, and Mr. Naylor, Chief Inspectors of the Mersey and Irwell, West Riding and Ribble Joint Committees.

The Thames Conservancy Board is a representative body consisting of thirty-eight members appointed or elected by the Admiralty, the Board of Trade, the Trinity House (for control over the "lower navigation" especially), by eighteen County Councils and Boroushs (including the London County Council), the Corporation of London, the Metropolitan Water Companies, by ship-owners, owners of sailing barges, dock-owners and wharfingers.

It is the oldest authority for prevention of pollution, powers 
for this purpose having been conferred upon it by Act of Parliament in 1866 .

Originally these powers werc limited to the main stream, and to the parts of its tributaries within three miles of the main stream.

By subsequent Acts these powers were extended to ten miles up the tributaries; but even then were found to be inherently defective as it was necessary to prove that pollution reached the main stream, and this was most difficult to do to the satisfaction of Magistrates.

Evidence was given before Lord Balfour's Commission in 1892 to this effect, and a recommendation was made by that Commission that powers should be extended to every part of the Thames Basin and that it should be an offence to pollute a tributary irrespective of the point whether the pollution reached the main stream.

This recommendation was carried into effect by the Thames Conservancy Act of 1894, which reconstituted the Thames Conservancy on lines more representative than theretofore.

The Conservators now have juriscliction for prevention of pollution to the very sources of the Thames and its tributaries, an area of nearly 4,000 square miles above the western limit of the Metropolis, as well as within narrowed limits below that point.

In the tideway great results have been effected by the manner in which the London County Council have treated the sewage of London. This, which was formerly discharged untreated into the river, is now dealt with in precipitation tanks and the solids are carried away to sea instead of passing into the Thames.

Above the tideway, or rather above the western limits of the Metropolis, the 4,000 square miles above referred to, the Conservators have a chief inspector, seven igspectors and eight assistants, whose work is clivicled into seven districts, an inspector and an assistant each working in one of these. Bicycles are used as a means of rapid transit.

Reports are received from those officers on every town, village, and hamlet in the area.

Notices have been served on all persons polluting, and reasonable time is given to carry out works for diversion. About 5,000 inspections are made yearly. Samples are constantly taken and analysed by the 'Thames Conservator's Analyst, Mr. C. E. Groves, F.R.S. These analyses now amount to 1,800 a year. The results of the Conservators' action are as follows, a large part of which have been carried out during the last four years. 
Summary showing the results of the action taken by the Conservators.

\begin{tabular}{|c|c|c|c|c|}
\hline $\begin{array}{l}\text { ABOVE THE INTAKES of the Hetropolitan } \\
\text { Water Companies. }\end{array}$ & Places. & Population. & $\left|\begin{array}{c}\text { Percent- } \\
\text { age of } \\
\text { whole } \\
\text { Populat'n. }\end{array}\right|$ & 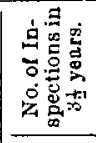 \\
\hline 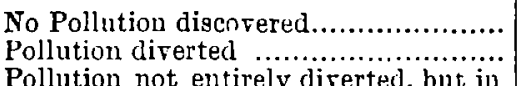 & $\begin{array}{l}590 \\
362\end{array}$ & $\begin{array}{l}210,705 \\
437,4 \geq 3\end{array}$ & $\begin{array}{l}10 \cdot 3 \\
40 \cdot 0\end{array}$ & $\begin{array}{l}5,480 \\
6,122\end{array}$ \\
\hline \multirow[t]{2}{*}{$\begin{array}{c}\text { course of diversion } \ldots \ldots \ldots \ldots \ldots \ldots \ldots \ldots \\
\text { Pollution not diverted }\end{array}$} & $\begin{array}{r}107 \\
86\end{array}$ & $\begin{array}{l}254,818 \\
189,161\end{array}$ & $\begin{array}{l}23 \cdot 4 \\
17 \cdot 3\end{array}$ & $\begin{array}{l}2,583 \\
2,408\end{array}$ \\
\hline & 1,145 & $1,092,107$ & 100 & 16,593 \\
\hline \multicolumn{5}{|l|}{$\begin{array}{l}\text { BELOW THE INTAKES of the Metropolitan } \\
\text { Water Compnnies, but above the Western } \\
\text { limits of the Metrepolis. }\end{array}$} \\
\hline $\begin{array}{l}\text { No Pollution discovered.................... } \\
\text { Pollution diverted ......................... } \\
\text { Pollution not entirely diverted, but in }\end{array}$ & $\begin{array}{l}19 \\
52\end{array}$ & $\begin{array}{r}6,248 \\
33+, 750\end{array}$ & $\begin{array}{r}1 \cdot 2 \\
65 \cdot 7\end{array}$ & $\begin{array}{r}121 \\
1,086\end{array}$ \\
\hline $\begin{array}{l}\text { course of diversion } \ldots \ldots \ldots \ldots \ldots \ldots \ldots \ldots . . . \\
\text { Pullution not diverted } \ldots . . \ldots \ldots \ldots \ldots \ldots \ldots\end{array}$ & $\begin{array}{l}24 \\
10\end{array}$ & $\begin{array}{r}147,634 \\
20,917\end{array}$ & $\begin{array}{r}29 \cdot 0 \\
4 \cdot 1\end{array}$ & $\begin{array}{l}449 \\
164\end{array}$ \\
\hline & 105 & $500,5+9$ & 100 & 1.820 \\
\hline
\end{tabular}

Mr. Groves says (June, 1898): "I might here point out that, owing to the action taken by the Thames Conservancy under the Act of 1894 , the amount of organic impurity dissolved in the water immediately above the intakes is now only about two-thirds of what it was before the passing of that Act."

On the anthorities who have not taken action, the Conservators are bringing pressure by proccedings before the Magistrates with great success.

The above statements will serve to give some idea of the methods of work and results attained by a conjoint committee of the largest and most important watershed in this country.

Not a spring, brook, or strem flows into our greatest river that does not come sooner or later under the supervision of the Board's inspectors; and it is difficult for the slightest pollution to escape detection.

Much still remains to be clone, for even from prehistoric times individuals and communities have clustered on the banks of the Thames and its tributaries, each to contribute its share of filthy refuse to the stream; and owing to the rapid growth of village, town and city in the present century, more than a million souls inhabit the banks of the tributaries or main river above the intakes, and more than five million below the intakes of the London water companies:-a total equal to nearly one-fifth of the whole population of England and Wales. 
For the abolition of such widespread pollution, time is of necessity required, partly owing to the legal subterfuges through which offenders can escipe from the performance of their duties, partly from actual local difficulties of dealing with sewage (such as are due to clay soil, lowness of level, etc.), and partly because of the uncertainty which prevails with regard to the best practical means available for purifying the eftluents.

Nevertheless the great work of purification progresses steadily, and it hardly needs the analysis of the chemist to show how greatly pollution has decreased since the Conservancy Board was entrusted with the task of preventing it.

The history of the prevention of pollution as carried out by the Thames Conservancy Board plainly shows the great adrantages to be gained by a combination of representative authorities on a large scale-through which combination economy and effectiveness are secured.

By obtaining control over the sources and tributaries of the river immense advantages are gained, much constant and futile litigation is replaced by authoritative and successful action, and consequently much time, labour, and moncy are sared.

Such desirable results it appenrs are almost impossible to obtain through the action of isolated and comparatively weak local authorities.

\section{Time Lee Conservancy Bo.rnis.}

The jurisdiction of the Lee Conservancy Board extends over the whole watershed area of the River Lee, an area of nearly 600 square miles. The main river and all its tributaries are under the control of the Boarcl, and provide a water supply to nearly two and a half million individuals.

The present Board of Conservancy was established by the Lee Conservancy Act of 1868 , and resembles the Thames Conservancy Board in its representative character.

A very interesting account of this Board and its works, together with a graphic description of the River Lec, its tributaries, and surroundings, is to be found in the excellent paper entitled "The River Lee up to Date," which was written by Major Lamorock Flower, especially for the Sanitary Institute in 1893. From this history many most useful and practical lessons may be learnt.

The inspection, the patrol, the safeguarding of this important river, from the main stream up to its smaller contributing sources, have during the last seren-and-twenty years been carried on by one individual-Major Lamorock Flower himself.

Major Flower has always adrocated individual action, in pre- 
ference to action by committee, for securing the abolition of pollution. IIe has insisted that a competent man entrusted, empowered, and controlled by the constituted Board, can through his personal influence, suider by tact and judrment, succeed far better in inducing polluters to abate their nuisances than mere ordinary officials, instructed by resolutions of committec, and armed with the hatef ul legal notice, which usually excites the wratl and all the combative tendencies in lim upon whom the notice has been served.

By exploring the valley of the Lee, either on foot or by water, you may see with your own eyes continuons evidence of pollution which has been direrted, or which is incessantly kept back, through the energy and watchfulness of the Board's entrusted agent.

The history of the river Lee also illustrates the fact that much pollution of our streams and rivers is often causerl unconsciously by owners of adjoining land or house property ; and that such per'sons, when their offences are brought before them by the right person, and in the right manner, are, in many cases, only too realy to remedy the evils for which they have unknowingly been responsible.

One blot in the Lee Conservancy Act cammot be passed unnoticed, viz., the clause which allows the carriage of house refuse, manure and gas lime on the river, generally in very old and Jeaky barges.

With regard to economy and cost. It might be thought that for the provision of such extensive and incessant supervision and control, a very large expenditure would be involved.

Such, however, is far from being the case, when the supervision and control are carried on under the direction of combined Boards, especially if we consider the vital importance of these measures, and the vast number of people who are thus protected.

In the case of the Lee Conservancy at any rate the total annual expenditure for all this supervision, inspection, and prevention of pollution, amounts to a sum, which, if charged to the water consumers, would be represented by a rate of a small fraction of a penny per annum.

\section{The Mersey and Inwell Joint Commitee and The West Riding Rivers Board.}

These two joint committees were constituted by Provisional Order of the Local Government Board; the former in 1891, the latter in 1893.

The Mersey and Irwell Joint Committee consists of representatives of the Counties of Lancaster and Chester, and 
of the County Boroughs of Bolton, Bury, Manchester, Oldham, Rochdale, Salford, and Stockport, representing in 1898 a population of nearly $2 \frac{1}{4}$ millions. The West Riding Board consists of members elected by the West Riding County Council, and by the County Boroughs of Leeds, Sheffield, Bradford, Halifax, and Huddersficld.

Each of these conjoint committees soon found out how defective the Rivers Pollution Act of $1876^{\circ}$ was, and almost within a year after their constitution sought for and obtained special Acts, upon the ground that "the restrictions contained within the said Act (1876) are such as to preclude effective. action by the joint committee."

It is on these two private Acts (which are almost identical) that the Bill of Sir Francis Powell is modelled.

Now whilst the Thames and Lee Conservancy Boards have to deal almost entirely with domestic sewage, the task and difficulties of the Conjoint Committees of the Mersey and Irwell and of the West Riding are enormously complicated by the great preponderance of "tracle effluents," by a mass of pollution which has rapidly accumulated during the last twenty or thirty years, and by the large and powerful industries which they are called upon to tax and correct in order to obtain right and lawful purification of the polluting effluents.

Thus Mr. Tatton, Clief Inspector of the Mersey and Irwell Board, reports in 1898, 90 sewage effluents in his district, 210 trade effluents passing into sewers, and 410 into rivers, whilst in the West Riding, Dr. Wilson reports 332 sewage disposal worlis and 2,103 trade effluents, $806^{\circ}$ of which pass into sewers, and 1,297 into streams.

\section{Method of Procedure.}

The method of procedure of each of these Committees appears to have been very much the same:-

1st. A considerable time was spent in inspecting, surveying, reporting, and classifying the various effluents throughout the whole district. At the same time manufacturers were approached in a friendly spirit, advised where they were transgressing the law, and made acquainted with the powers of the Conjoint Committee.

The effect of these steps has generally been to bring about a considerable amount of voluntary reform and improvement.

The next step las been to send round notice requiring that a scheme for the purification of the trade effluents should be adopted where it was required. From this further improvements have resulted. 
After allowing due time pressure has been brought to bear, and ultimately action has been taken in cases where the offenclers omitted or refused to comply with the requirements of the Board.

In this way steady though slow progress has been made.

So far as I can judge from the evidence before me, every consideration has been shown by the Committees to the manufacturers, so as not to embarass them unduly or interfere unfairly with their industrics, ample time has been allowed for elaborating schemes for purification, and every possible assistance and advice has been given by the Committee to help in the accomplishment of this of tentimes difficult and complicated task.

On the other hand, the manufacturers, as a rule, appear to have met the committees in a liberal and fair spirit, although to many of them the cost of constructing works has been very considerable.

In the West Ricling definite improrement is already evident in the manufacturing and sewage pollutions, and more especially in the solid pollutions, although the Board has been in action for a comparatively short period.

The fine laboratory of the Board which was brought into use in September, 1897, gives every facility for analysis of sewage effluents and trade refuse. On visiting there in Jume, through the kindness of Dr. Wilson and Mr. Halliwell, I had the opportunity of studying a most instructive pathological collection of nearly every kind of foul tracle refuse. Experiments on the treatment of these effluents are being carried on in the laboratory and it is hoped that the experimental work will be of great use to manufacturers in assisting them to discover the best means of purifying their tracle refuse.

In the Mersey and Irwell District, which had two years start of the West Riding, the resulting improvements are still more marked.

Very few trade effluents remain untreated. The upper tributaries of the rivers are palpably clearing. The deposits of cinders and sludge lower down are very much diminished. It is encouraging to find that the manufacturers are already benefitting in that the water supplied to them requires less sedimentation and filtration before use in their mills, \&c., whilst the foul materials which used to pollute the river are in several instances recovered with profit to the manufacturer, notably in paper making and coal washing, thus illustrating the wise adacre that "dirt is but matter in the wrong place." In all probability it will be found that materials of some value 
may be extracted from most trade eftuents. In fact as Shakespeare tells us :

"There is some soul of gondness in things evil,

Would men observingly distil it out."

All this seems almost too good to be true.

If such improvements can be produced in the face of such difficulties, there seems no reason why the purification of our streams and rivers should not be accomplished quickly and steadily, if the Act of $1876^{\circ}$ be reformed in the few necessary details, and if conjoint committees, organised on the same lines as those of the Thames, Lee, Mersey and Irwell, West Riding ancl Riljble, having control over whole watersheds, or groujs of streams and rivers, be established throughout the country.

\section{Tine Ribible Jomt Commtter.}

The history of the Ribble Joint Committee, which was constituted by Provisional Order in 1891, illustrates the great advantage of placing a whole watershed area (or the greater part of it) under the control of a joint committee, even if no special Act be obtained for the district. The reduction and abolition of pollution has steadily progressed in this watershed; in many cases profit has been grained by purifying the effluents; whilst it is claimed that muder the Act of 1876 , with all its defects, the good work of the Ribble Conjoint Committee compares not unfarourably with that of the other Boards.

In the remarks which 1 have been privileged to make to you I feel conscious of many omissions and defects, but I trust that you will make some allowance on account of the magnitude and complexity of the subject compared with the short time at my disposal. Amongst other things the pollution of our wells and subsoil water, which is undoubtedly the cause of most "waterborne typhoid fever," is a subject of such vast importance that it could not be dealt with in the same lecture.

It is impossible, howerer, to pass over the burning question of the responsibilities of waterwork companies and the relations of those companies to sanitary authorities.

The following resolutions, which I proposed at the cliscussion on "Waterborne Typhoid," in March, were carried unanimously, and are at present under the consideration of the Council :-

That the Council of the Institute be requested to consider the best means for obtaining new and effective legislation for the protection of our water supplies from pollution, whereby it shall be enacted that-

(1) All local Sanitary Authorities shall have free access to 
the water supplies-from source to distribution-which are distributed within their districts, whether the source and course of the water so supplied be within their district or not. That the Sanitary Authorities provide for the thorongh and regular inspection of the water supplies clistributed within their clistricts, and for the regular analysis of such water, as often as may be deemed sufficient, and that the results of such inspections and analyses shall be regularly recorded and published,

(2) That the waterworks companies shall prepare and publish records of their water supplics; such records containing a full account of every somrce and tributary of the water supply, and a full account of all reservoirs, conduits, filter-beds, mains, and pipes by which the water which they supply is collected, stored, or conveyed, to the houses supplied; such records also being fully illustrated by maps, plans, and sections, showing the relation of all houses, drains, sewers, cesspits, and all deposits of organic refuse in the immediate neighbourhood of any part of the water supplied by them, and that all such records, maps, plans, sections, \&c., shiall be freely accessible for the purposes of inspection to the sanitary authority within whose district the water is supplied, and to every customer of the waterworks company.

(3) That the Water Companies shall be required to make regular, constant, and thorough inspection of all parts of their waterworls - from source to distribution - with a view to preventing wilful, careless, or acciclental pollution; also to make regular analyses of the water supplied by them, so often as may be considered necessary; and to make and publish reports of all such inspections and analyses.

(4) That, Waterworks Companies shall be made responsible for the consequences of the pollution of water supplied by them, if such pollution could reasonably have been prevented.

(j) That wilful or careless pollution of any water supply shall be regarded and treated as a penal offence.

We have been accustomed to rely chiefly upon our waterwork companies for securing us agrainst the introduction of poisonous material into the water with which the companies supply us, and which we have to drink, if we drink any water at all.

But under the existing state of the law the obligations laid on the companies are so insufficient that we have no ground for such confidence.

The disastrons epidemics which have occured in recent times hive opened the eyes of the public to this fact, and roused them from their indifference to such an extent that the necessary reforms will be insisted upon at the earliest opportunity. 
Parliament also appears to be ready for action, for although the clauses proposed by $\mathrm{Mr}$. Chaplin last June, to be addedwith a view to protecting the consumers - to twenty-one private water bills were withdrawn, the withdrawal was urged upon technical grounds, and all who spoke on the subject appeared to be ready to support those clauses if introduced in a public bill.

On looking at these clauses of Mr. Chaplin's, I am astounded to find that the provision which, in my mind, is by far the most important one has been entirely omitted;-viz., the regular and constant inspection and supervision of all parts of the watersupply-from source to distribution.

Instead of that the taking and examination of samples is entirely relicd upon for the detection and prevention of pollution.

Combined with thorough and regular inspection of the watersupply, it is true, chemical and bacteriological analysis can be of great service, for they can give indication of pollution which could not be detected merely by inspection.

If relied upon alone they give a false sense of security.

Even if the analyses were made daily they would not enable us to prevent pollution, they can only detect the pollution after it has taken place.

As a rule water-borne outbreaks of typhoid fever occur with explosive violence; so that most of the victims have imbibed the poison before the alarm conveyed by the means of analysis can possibly save them from infection.

It is to be hoped that these reforms will be carried out as soon as possible, and that the serious omission with regard to inspection will be remedied.

I trust, however, that amidst the agitation which springs out of recent calamity and alarm the old standing evil will not be forgotten; that the nation will awake to a sense of the disgrace, loss, and danger which must always exist as long as this foul and illegal pollution of our streams is suffered to continue.

If the idea of constituting joint committees to control whole watersheds or groups of streams, according to circumstances and convenience, be approved of, I appeal to the Institute, to this Congress, to all concerned in the health and welfare of the nation, to do all that is possible to urge the Local Govermment Board that they shall give every facility and encouragement for the formation of such joint committees. But, above all, I hope and trust that you and all who are so concerned will give cordial support to the Rivers Pollution Prevention Bill by which the defective Act of 1876 will be amended, and through which we may hope eventually for the total abolition of the pollution of our streams and rivers throughout the United Kingdom. 